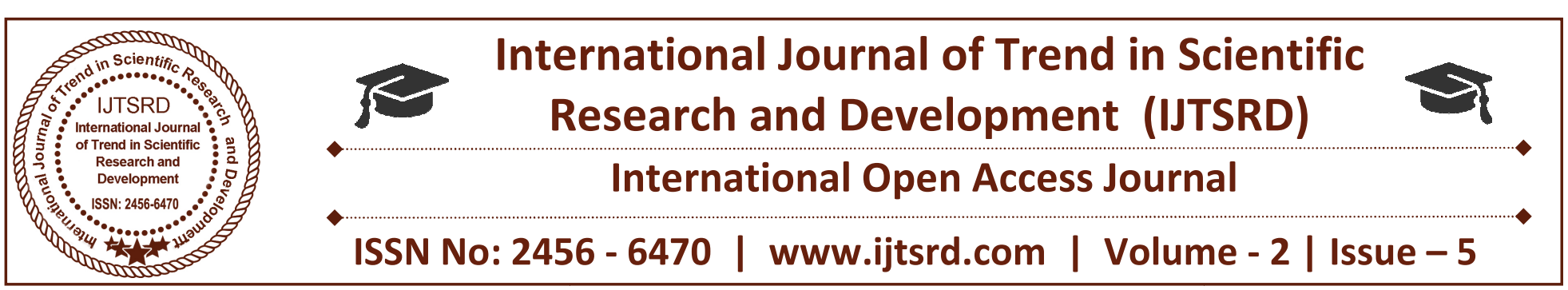

\title{
Current Scenario of the E-Governance Initiatives, and Future Prospects in India
}

\author{
Dr. P. Chinnathurai ${ }^{1}$, Arsheed Javid ${ }^{2}$ \\ ${ }^{1}$ Associate Professor, ${ }^{2}$ PhD Research Scholar \\ Department of Political Science and Public Administration, Annamalai University, \\ Chidambaram, Tamil Nadu
}

\begin{abstract}
:
E-Governance the application of ICT to transform the efficiency, effectiveness, transparency and accountability of exchange $\mathrm{f}$ information and
\end{abstract} transaction between government, between government agencies, between government and citizens, between government and business. Through e-governance, government services will be made available to citizens in a convenient, efficient and transparent manner. Moreover, today's government has also full faith in E-Governance and its widespread network across the world proves it. Due to widespread demand of e-governance and exponentially increasing size of data, new technologies like Open source solutions and cloud computing need to $\mathrm{Ve}$ incorporated. Development of any country can be judged by the scope of e-governance in that country. This new paradigm has brought about a revolution in the quality of service delivered to the citizens. It has ushered in transparency in the governing process; saving of time due to provision of services through single window; simplification of procedures; better office and record management; reduction in corruption; and improved attitude, behavior and job handling capacity of the dealing personnel. The National e-Governance Programme (NeGP) which is the flagship e-governance programme of the Union Government, was approved by the Government of India on May 18, 2006 comprising with 27 Mission Mode Projects (MMPs) at the Central, State and Local Government level. The NeGP aims at improving delivery of government services to citizens and businesses with a vision to make the services accessible to the common man while ensuring efficiency, transparency, reliability and effective delivery of services at affordable costs.
In this paper we present an overview of e-governance projects which are being used in India and the current status of these e-Governance related initiatives and problems based on secondary data received from various sources.

Keywords: E-governance; NeGP; ICT; Future Prospects etc.

\section{INTRODUCTION}

With India's vast population and geographic dispersion, one of the real challenges faced by the government is to reach every citizen at the grass root level and provide them with information and access to different government services. This has made it difficult for the people to leverage the full potential of government initiatives. The infusion of Information and Communication Technology (ICT) has played a prominent role in overcoming this challenge. The metamorphosis in the quality of delivery of services to the citizens by the government has been more pronounced in recent years with the advent of egovernance. E-Governance is the application of Information and communications technology to government functioning in order to create 'Simple, Moral, Accountable, Responsive and transparent' (SMART) e-Governance provides a sound strategy to strengthen overall governance. It can not only improve accountability, transparency and efficiency of government processes, but also facilitate sustainable and inclusive growth. An effective eGovernance policy will eventually lead to the following advantages:-

$>$ Exchange of information with citizens, businesses or other government departments 
International Journal of Trend in Scientific Research and Development (IJTSRD) ISSN: 2456-6470

$>$ Speedier and more efficient delivery of public services

$>$ Improving internal efficiency

$>$ Reducing costs / increasing revenue

$>$ Re-structuring of administrative processes

Improving quality of services.

\section{E-Governance in India}

The e-Governance vision has been drafted online with the development goals and governance agenda of the current Government. Various State documents have been refereed to understand the development goals, governance style of the current government along with the strategic discussions with the Government, keeping in view the needs and expectations of the citizens, businesses and other stakeholders The objective of the IT policy with respect to eGovernance is to use e-governance as a tool and deliver a government that is more proactive and responsive to its citizens by playing an active role.

The establishment of the National Informatics Centre (NIC) in 1977 was the first major step towards eGovernance in India as it brought information and its communication in focus. National Informatics Centre (NIC) is playing a vital in the implementation of egovernance by designing and launching various types of web portals and online management information systems.

The main thrust for e-Governance was provided by the launching of NICNET in 1987 - the national satellite-based computer network. A National Task Force on Information Technology and Software Development was constituted in May 1998. In 1999, the Union Ministry of Information Technology was created. In the year of 2000, IT Act was passed and eGovernance got its legal reorganization. After implementation of RTI Act, 2005 Government information such as various Cabinet Decisions, forms, procedures, programs, projects, schemes, tenders, quotation calls, notice etc. started being displayed in the State Portal for reference and use by the public. Designated Information Officers in individual Departments and offices are now responsible to provide all information needs.

\section{E-Governance Initiatives at State Level}

There have been continuous efforts from government in India to provide citizen services in a better manner utilizing e-governance. Quite a number of state governments have initiated measures to introduce information technology and its tools in the governance process. Some of the successful initiatives undertaken in various states of India are:

\begin{tabular}{|c|c|}
\hline $\begin{array}{l}\text { Andhra } \\
\text { Pradesh }\end{array}$ & $\begin{array}{l}\text { e-seva, card, VOICE, MPHS, FAST, } \\
\text { e-cops, Saukaryam }\end{array}$ \\
\hline Bihar & $\begin{array}{l}\text { Sales Tax Administration } \\
\text { Management Information }\end{array}$ \\
\hline Delhi & $\begin{array}{l}\text { Automatic Vehicle Tracking System, } \\
\text { Computerization of website of RCS } \\
\text { office, Electronic Clearance System, } \\
\text { Management Information System for } \\
\text { Education etc }\end{array}$ \\
\hline Kerala & $\begin{array}{l}\text { e-Srinkhala, RDNet, Fast, Reliable, } \\
\text { Instant, Efficient Network for the } \\
\text { Disbursement of Services . }\end{array}$ \\
\hline Goa & Dharani Project \\
\hline Chhattisgarh & $\begin{array}{l}\text { Chhattisgarh InfoTech Promotion } \\
\text { Society, Treasury office, e-linking } \\
\text { project }\end{array}$ \\
\hline Gujarat & $\begin{array}{l}\text { Dairy Information System Kiosk } \\
\text { (DISK), Form Book Online, Census } \\
\text { Online, Tender Notice }\end{array}$ \\
\hline $\begin{array}{l}\text { Jammu } \\
\text { and } \\
\text { Kashmir }\end{array}$ & $\begin{array}{l}\text { Common Service Centers, Websites } \\
\text { of different districts of the entire } \\
\text { state, Vahan \& Sarathi for } \\
\text { automation of Registration related } \\
\text { transactions and license related } \\
\text { transaction respectively, Secretariat } \\
\text { Knowledge Information } \\
\text { Management System eoffice }\end{array}$ \\
\hline $\begin{array}{c}\text { Himachal } \\
\text { Pradesh }\end{array}$ & Lok Mitra \\
\hline Tamil Nadu & $\begin{array}{l}\text { Application Forms Related to Public } \\
\text { Utility, Tender Notice \& Display }\end{array}$ \\
\hline Maharashtra & $\begin{array}{l}\text { SETU, Koshvani, Telemedicine } \\
\text { Project, Online Complaint } \\
\text { Management System Mumbai }\end{array}$ \\
\hline Pune & $\begin{array}{l}\text { SUWIDHA(Single User Window } \\
\text { Disposal Help Line for } \\
\text { Applicants),SUBS (Suwidha } \\
\text { Backend Services), SSIS (Social } \\
\text { Security Information System) } \\
\text { WEBPASS (District Passport } \\
\text { Application Collection Centre) }\end{array}$ \\
\hline Rajasthan & $\begin{array}{l}\text { Jan Mitra, RajSWIFT, Lokmitra, } \\
\text { RajNIDHI }\end{array}$ \\
\hline Uttarkhand & $\begin{array}{l}\text { Kisan Soochna Kutirs (KSKs), } \\
\text { Village Information Centre (VICS), } \\
\text { Computerization of Land Record } \\
\text { Department }\end{array}$ \\
\hline
\end{tabular}




\begin{tabular}{|c|l|}
\hline Karnataka & Bhoomi, Khajane, Kaveri \\
\hline & Gyandoot, Gram Sampark, Smart \\
Madhya & Card in Transport Department, \\
Pradesh & $\begin{array}{l}\text { Computerization MP State } \\
\text { Agricultural Marketing Board } \\
\text { (Mandi Board) etc }\end{array}$ \\
\hline
\end{tabular}

\section{Current Status of E-Governance in India}

E-Governance is a stepping stone to a more civilized and organized nation. The use of Information and Communication Technologies (ICTs) are acting as the backbone for the implementation of e-Governance. eGovernance is expected to play a significant role in reducing red-tapism and give way for a better bureaucracy in India, with a promise to reduce corruption and bring transparency. India is a country with a population of 1.2 billion people, where it becomes challenging to uproot corruption from the roots of the country; so e-Governance will help to keep a check on it.

1. Computers came to India in 1959 but were slow to catch on. There was a feeling amongst employees of the establishments introducing computers in the initial stages that would replace workers and result in loss of jobs.

2. In 1975, the Government of India decided to introduce the use of computers in government and computer based decision support system in the ministers and departments to facilitate planning and programme implementation

3. During 1985-90, NIC reached out to 550 districts headquarters in the country and established a nationwide ICT Network called NICNET in 1988

4. In May 1998, a National Task force was set up which had mandate to formulate the draft of a National Informatics Policy.

5. During the Ninth Five year plan period, there was stress on the total IT sector and there was no mention of e-Governance. mid-way through the plan came the 3 percent mandate and the responsibility of IT industry as well as using IT in government shifted to the new Ministry of information technology.

6. The Tenth Five year plan defined the scope of eGovernance and mentioned that it involves transformation from being a passive information and service provider to active citizen involvement. It was suggested in the report that the master plan on e-Governance should develop a clearly focused vision of the objective of introducing eGovernance.

\section{National E-Governance Plan (NeGP)}

Government formulated National E-Governance Plan (NeGP), across the country with following vision:

-Make all Government services accessible to the common man in his locality, through common service delivery outlets and ensure efficiency, transparency \& reliability of such services at affordable costs to realize the basic needs of the common man.

\section{E-Governance initiatives in India under NeGP}

Significant progress has been made in the implementation of the core and support components under NeGP. Major achievements are highlighted below:

\section{STATE WIDE AREA NETWORKS: -}

In March 2005, the Government of India approved the scheme for establishing State Wide Area Networks (SWANs) across the country [Poonam Malik, Priyanka Dhillon, Poonam Verma, 2014]. Under this Scheme, technical and financial assistance are being provided to the States/UTs for establishing SWANs to connect all State/UT Headquarters up to the Block level via District/ sub-Divisional Headquarters with a minimum bandwidth capacity of $2 \mathrm{Mbps}$ per link. To monitor the performance of SWANs, the Department has mandated positioning Third Party Auditor (TPA) agencies by the States/UTs. Steps have been initiated to integrate all SWANs using the National Knowledge Network (NKN). Four States namely Gujrat, Tamil Nadu, Karnataka and Andhra Pradesh have been integrated using NKN. The SWANs in 28 States/UT i.e. Andhra Pradesh, Chandigarh, Chhattisgarh, Delhi, Gujarat, Haryana, Himachal Pradesh, Jharkhand, Kerala, Karnataka, Lakshadweep, Maharashtra, Orissa, Punjab, Puducherry, Sikkim, Tamil Nadu, Tripura, Uttar Pradesh, West Bengal, Assam, Bihar, Madhya Pradesh, Uttarakhand, Manipur, Arunachal Pradesh, Meghalaya and Mizoram have been operational. The SWANs in Nagaland are in advanced stage of implementation. Rajasthan has identified the Network Operator and implementation is underway. J \& $\mathrm{K}$ have initiated the bid process to identify the Network Operator for implementation. Dadra \& Nagar Haveli, Daman \& Diu and Andaman and Nicobar are in RFP/BOM finalization stage.

\section{STATE DATA CENTRES (SDCs):-}

The State Data Center (SDC) is being implemented across the country to provide common IT infrastructure to host Government applications. SDC is one of the three infrastructure pillars structured 
under NeGP to facilitate web enabled Anytime, Anywhere 74 access. SDC is conceptualized with the objective of providing a common enabling infrastructure to the States / UTs to consolidate services, applications and infrastructure to provide efficient electronic delivery of G2G, G2C and G2B services. Substantial progress has been made in the SDC project. The table below shows the implementation status of SDC'c

\section{COMMON SERVICE CENTRES (CSCs):-}

The CSC Scheme as approved by Government of India in September 2006 for setting up of 100,000+ (one lakh) internets enabled centres in rural areas under the National E-Governance plan (NeGP) is being implemented in a Public Private Partnership (PPP) mode. The Common Services Centres (CSC) are proposed to be the delivery points for Government, Private and Social Sector services to rural citizens of India at their doorstep. The State Governments like Andhra Pradesh, Assam, Bihar, Gujarat, Haryana, Jharkhand, Kerala, Maharashtra, Orissa, Rajasthan, Tamil Nadu, Uttar Pradesh and West Bengal have issued Government Orders / Notifications to the various departmental heads / District Level authorities/ Stakeholders for use of CSC to for e- Governance Projects has been developed for ministries and departments to facilitate the voice and space for citizen participation in EGovernance, especially for the weakest and the most marginalized sections of society for whom the eGovernance projects are created to serve the most

\section{Passport Seva project: -}

The Central Passport Organization (CPO) launched the Passport Seva Project in partnership with the Ministry of External Affairs with an objective of delivering passport services to the citizens in a timely, transparent and reliable manner. The project started with gathering all the system data for the $\mathrm{CPO}$ and creating infrastructure, procuring hardware and training employees for pilot projects. This included setting up of 77 Passport Seva Kendras (PSKs), a data centre, a disaster recovery centre and a call centre that would operate $18 \times 7$ in 17 languages, and a centralised nationwide computer system that would issue passports. This was followed by setting up and running pilot sites and consequently rolling out the service at national level. The Passport Seva Project has resulted in the following benefits:

\section{E-office:}

This project was launched by Department of Administrative Reforms and Public Grievances
(DAR\&PG) to develop an integrated system of record and file management. It aims to introduce the concept of e-file (electronic files), rule based file routing, flexible workflows and digital signatures for authentication, thus leading to a paperless environment.

With the deployment of the above measures, the government aims to improve efficiency, consistency and effectiveness of government responses. Additionally, it intends to reduce turnaround time, processing delays and establish transparency in the system.

\section{Future Prospects of e-Governance}

1. To deliver all kind of govt. services through electronic mode. It will make government transparent, efficient and easily accessible to citizens to get benefitted of various services by way of e-governance.

2. In order to reach out the citizens from remote control areas, mobile governance to be given priority, through which ,both transactional and informational govt. services provided and providing innovation in mobile governance.

3. Govt. to try so as to infuse advanced technology for executing the ongoing projects to greater extent. It would keep the sustainability of multiple projects.

4. To create an eco-system that promotes innovation in ICT for govt. and for applications that can benefit the citizens.

5. "To promote ethical use of e-governance services. In which, keeping the information of govt., private institutions safer and securing e-govt. cyber world.

\section{Conclusion}

In this paper, we have given a list e-Governance projects run by state and central governments and the current status of these e-governance related initiatives based on secondary data received from various sources. Although government of India has taken significant steps towards successful implementation of e-governance but despite of that, there are some factors like delay in project implementation, spiraling cost, financial feasibility and financial sustainability along with technical bottlenecks and Integration with Government departments and states may affect in successful implementation. In future India will be having complete e-governance which will radically change the face of governance and provide its citizens, an interface to get better and more efficient government services. 
The paper will be incomplete without giving a direction to our Strategy and this direction comes in words of, Dr. APJ Abdul Kalam, former President of India and a visionary in the field of e-Governance has aptly summarized the basic challenge lying before the country in this regard:"e-Governance, has to be citizen-friendly. NIC is providing the network backbone and a wide range of ICT (Information and Communication Technologies) services to government organizations throughout India. Several drafts have also been passed by IT department to implement E-Governance with these technologies so that working, efficiency, transparency and security can be increased in e-Governance.

\section{References}

1. Gupta, M.P. (2016). Towards E-Government Management Challenges, Tata McGraw-Hill Publishing Company Limited, New Delhi

2. E-Readiness Ranking 2017, The Global Information Technology Report 2012 by Economist Intelligence Unit.

3. [Monga A, 2008] Monga A (2008). E-government in India: Opportunities and challenges, JOAAG, Vol. 3. No. 2, 2008.

4. Heeks, R.B. (2002) 'Information systems and developing countries: failure, success and local improvisations', The Information Society, 18(2), 101-112

5. N. S. Kalsi, Ravi Kiran and S. C. Vaidya, Effective e-Governance for Good Governance in India, International Review of Business Research Papers, Vol.5 No. 1 January 2018 Pp. 212-229

6. Nikita Yadav \& V B Singh, 2016] Nikita Yadav \& V B Singh (2016). E-Governance: Past, Present and Future in India, International Journal of Computer Applications, Volume 53 - No. 7, September

7. [Panwar \& Vaibhav, 2008] Panwar, Vaibhav (2015), "Role of data warehousing \& data mining in egovernance,"2008.

8. Richard Heeks1(2001), Understanding eGovernance for Development, IDPM, University of Manchester, UK

9. Community Information Centre Web site http://www.cic.nic.in la last visited30 Sep

10. "E-Governance in India" by Suneel Kumar, Imperial Journal of Interdisciplinary Research (IJIR) Vol-2, Issue-2, 2016, ISSN: 24541362available at http://www.onlinejournal.in

11. Kochhar Sameer and Gursharan Dhanjal, (2005). E-government Report Card, Yojna, Vol.49, August, New Delhi 